\title{
Beneficial effects of lipids and prolactin on insulin secretion and $\beta$-cell proliferation: a role for lipids in the adaptation of islets to pregnancy
}

\author{
T Clark Brelje, Nicholas V Bhagroo, Laurence E Stout and Robert L Sorenson \\ Department of Genetics, Cell Biology and Development, University of Minnesota Medical School, 6-160 Jackson Hall, 321 Church Street, SE, Minneapolis, \\ Minnesota 55455, USA \\ (Correspondence should be addressed to R L Sorenson; Email: soren001@umn.edu)
}

\begin{abstract}
To meet the increased demand for insulin during pregnancy, the pancreatic islets undergo adaptive changes including enhanced insulin secretion and $\beta$-cell proliferation. These changes peak in mid-pregnancy and return to control levels by parturition. Because lactogens (placental lactogen and/or prolactin) induce this up-regulation and remain elevated throughout gestation, we examined whether lipids alter the effects of prolactin on islets. In response to prolactin, there was a $2 \cdot 5$-fold increase in insulin secretion when compared with control islets. There was also a $2 \cdot 5$-fold increase in insulin secretion in response to palmitate and a fivefold increase when islets were cultured with a combination of prolactin and palmitate. After culture with prolactin and palmitate, acute stimulation with $10 \mathrm{mM}$ glucose for $1 \mathrm{~h}$ showed a suppression of insulin release. However, including palmitate in the stimulation media (a condition similar to late pregnancy in vivo) restored a higher rate of insulin release. This suggests that elevated lipids in late pregnancy lead to enhanced insulin secretion that is increasingly dependent on
\end{abstract}

lipids and less sensitive to glucose. $\beta$-Cell proliferation was also increased sixfold by prolactin and threefold with palmitate. The combination of both was slightly more than additive (11-fold). Similar experiments with oleate had no effect on insulin secretion. However, oleate stimulated $\beta$-cell division by threefold and was synergistic with prolactin (21-fold). These results were repeated in experiments including normal serum. Interestingly, prolactin also blocked the reduction of glucokinase levels observed with fatty acids. Overall, these results suggest that increased lipids during pregnancy likely contribute to the adaptation of islets to pregnancy by further enhancing $\beta$-cell division. In addition, the increase in lipids leads to enhanced insulin secretion that is less sensitive to glucose and more dependent on lipids. This provides a potential mechanism for maintaining elevated insulin secretion until parturition while preparing islets for normal glucose sensitivity post partum. Journal of Endocrinology (2008) 197, 265-276

\section{Introduction}

During pregnancy, there is an increased need for insulin to accommodate the developing insulin resistance and growing fetal compartment. The pancreatic islets of Langerhans meet this demand by increasing both insulin secretion and islet mass (Parsons et al. 1992, Sorenson \& Brelje 1997). Glucosestimulated insulin secretion from isolated perfused rat pancreases during pregnancy was increased by day 10 , peaked on day 15 , and then declined to near control levels by parturition (Parsons et al. 1992). This increase in glucose-stimulated insulin secretion is accompanied by a lowering of the threshold for glucose stimulation from $5.5 \mathrm{mM}$ glucose in controls to $3.3 \mathrm{mM}$ glucose in mid-pregnancy. Islet mass is also increased $1 \cdot 5-$ to 2-fold during pregnancy in rats (Parsons et al. 1995, Sorenson \& Brelje 1997). $\beta$-Cell proliferation during pregnancy in rats was increased by day 10 , peaked on day 14 , and declined to control levels after day 18 (Parsons et al. 1992).
Through a series of in vivo and in vitro studies, we have shown that the activation of prolactin receptors by lactogenic hormones, either placental lactogen or prolactin, induces all of the known up-regulatory changes in islet function, which are known to be characteristic of pregnancy (Brelje \& Sorenson 1988, Brelje et al. 1989, 1993). The length of time required to induce these changes is similar to that observed during pregnancy. In addition, in none of the experiments was a decrease in islet function observed with continued stimulation with prolactin. Since placental lactogen remains elevated until parturition (Parsons et al. 1992), additional factors must be responsible for the decline in glucosestimulated insulin secretion and $\beta$-cell proliferation from their peaks in mid-pregnancy to control levels by parturition. However, serum lipids, triglyceride, and free fatty acids also increase several fold during pregnancy (Scow et al. 1964, Knopp et al. 1973, Chen et al. 1992). This elevation is first observed in rats between days 11 and 14 of pregnancy and 
peaks on the last 2 days of pregnancy. As a result, peak lipid concentrations coincide with the decline of glucosestimulated insulin secretion and $\beta$-cell proliferation to control levels by parturition. This marked increase in serum lipids is of particular interest considering the powerful interaction between glucose and fatty acids in the regulation of normal $\beta$-cell function (Nolan et al. 2006, Poitout et al. 2006, Prentki $\&$ Nolan 2006). Thus, lipids may have a role in modulating islet $\beta$-cell function in the latter half of pregnancy. Since palmitate and oleate are among the fatty acids that increase during pregnancy (Chen et al. 1992), we investigated their influence on the effects of prolactin in cultured islets. These conditions should mimic those islets experience during late pregnancy in vivo when they are exposed to high circulating levels of both lactogens and lipids.

\section{Materials and Methods}

\section{Hormones}

The rat prolactin (NIDDK-rPRL-B-8-SIAFP) was provided by the National Hormone and Pituitary Program (Dr A F Parlow, National Hormone and Pituitary Program, University of California Los Angeles Medical Center, Torrance, CA, USA).

\section{Rat islet isolation and culture}

The pancreatic islets were isolated from 3- to 5-day-old Sprague-Dawley rats (Sasco, Omaho, NE, USA) by a nonenzymatic culture method described previously (Hegre et al. 1983). After this initial culture, groups of 30 islets were cultured free floating in 24-well plates (Costar, Cambridge, MA, USA) in $2 \mathrm{ml}$ RPMI-1640 with $10 \mathrm{mM}$ glucose supplemented with $1 \%$ fatty acid-free BSA (Sigma), $10 \mathrm{mM}$ HEPES, $2 \mathrm{mM}$ GlutaMax (Gibco), and $1 \%$ penicillinstreptomycin-fungizone antibiotic-antimycotic (Sigma) at $37^{\circ} \mathrm{C}$ in a humidified atmosphere of $5 \% \mathrm{CO}_{2}$ in air. The effects of prolactin and fatty acids on islet function were examined by culturing islets for 4 or 8 days with $500 \mathrm{ng} / \mathrm{ml}$ rat prolactin and/or $0 \cdot 05-0.80 \mathrm{mM}$ of either palmitate or oleate. The medium was changed each day and the amount of insulin released into the culture media determined. All procedures using animals were approved by the Animal Care and Use Committee of the University of Minnesota.

\section{Fatty acid solutions}

Stock solutions of the sodium salts of palmitic and oleic acids were prepared as follows (Briaud et al. 2001): the fatty acids were dissolved in $25 \%$ ethanol at $50{ }^{\circ} \mathrm{C}$ at a final concentration of $150 \mathrm{mM}$. Aliquots of stock solutions were complexed with fatty acid-free BSA $(10 \%$ solution in culture media) by stirring for $1 \mathrm{~h}$ at $37^{\circ} \mathrm{C}$ and then diluted with additional culture medium. The final BSA concentration was $1 \%$ with a molar ratio of fatty acid:BSA of $5: 1$ or less depending on fatty acid concentrations. The final ethanol concentration in culture was $\leq 0 \cdot 12 \%$ (vol:vol). All control conditions contained the same amount of BSA and an equivalent amount of ethanol.

The concentrations of free fatty acids were calculated according to the method of Richieri et al. (1993). In serumfree media, $0.4 \mathrm{mM}$ palmitate or oleate bound to $1 \% \mathrm{BSA}$ should result in 16.7 and $24.9 \mathrm{nM}$ free fatty acids respectively. For experiments using 10\% horse serum (assuming albumin is $4.5 \%$ horse serum), $0.6 \mathrm{mM}$ palmitate or oleate bound to $1 \% \mathrm{BSA}$ in $10 \%$ horse serum should result in $17 \cdot 6$ and $26 \cdot 6 \mathrm{nM}$ free fatty acids respectively. Assay values for free fatty acids in normal horse serum were expected to be $0.5 \mathrm{mM}$ (Zimmerman et al. 1992), thus the concentrations of $10 \%$ horse serum would expected to be $0.05 \mathrm{mM}$.

\section{Insulin secretion and insulin content}

For the assessment of glucose-stimulated insulin secretion in static incubations, batches of 30 islets were washed thrice in Krebs-Henseleit buffer containing 1\% BSA, 10 mM HEPES, and $2.8 \mathrm{mM}$ glucose for $20 \mathrm{~min}$. After this pre-incubation, the islets were incubated for $60 \mathrm{~min}$ in the presence of $5.6 \mathrm{mM}$ glucose followed by $60 \mathrm{~min}$ in the presence of $10.0 \mathrm{mM}$ glucose. In parallel trials, $0.4 \mathrm{mM}$ palmitate was also included in the stimulation medium. The amount of insulin released into the media during the $1-\mathrm{h}$ incubations was then determined. Intracellular insulin content was measured in each batch of 30 islets after acid-alcohol extraction. Insulin was measured using a sensitive rat insulin RIA (Linco Research, St Charles, MO, USA).

\section{Islet cell proliferation}

To estimate islet $\beta$-cell proliferation, $10 \mu \mathrm{M}$ 5-bromo- $2^{\prime}$ deoxyuridine (BrdU) were added during the final 12-h culture (Brelje \& Sorenson 1991). The islets were rinsed with Hank's balanced salt solution (HBSS), fixed in 4\% paraformaldehyde for $30 \mathrm{~min}$, and incubated in $2.0 \mathrm{M} \mathrm{HCl}$ for $20 \mathrm{~min}$. The BrdU-labeled nuclei were identified by staining overnight at $4{ }^{\circ} \mathrm{C}$ with a 1:200 dilution of a mouse monoclonal anti-BrdU antibody (Caltag Laboratories, San Francisco, CA, USA) and a 1:600 dilution of a CY3·18-conjugated donkey anti-mouse IgG (Jackson ImmunoResearch Laboratories, West Grove, PA, USA). Because of the large size of intact islets, glass beads of 50-100 $\mu \mathrm{m}$ maximal diameter were included in the mounting media to support the cover slips and prevent excessive deformation of the islets. The number of BrdU-labeled nuclei per islet was counted by direct observation with a conventional epifluorescence microscope with a minimum of 75-100 islets examined per condition. To facilitate comparison of data, changes in islet cell proliferation are expressed as fold the value observed in control islets $(2 \cdot 6 \pm 0 \cdot 3 \mathrm{BrdU}-$ labeled nuclei/islet for all experiments). 


\section{Islet cell viability}

To estimate the rate of cell death in islet $\beta$ cells, $1 \mu \mathrm{M}$ of the cell impermeant nucleic acid stain YoYo-1 (Molecular Probes, Eugene, OR, USA) was added during the final 3-h culture (Weinhaus et al. 2000). The islets were rinsed with HBSS and fixed in $4 \%$ paraformaldehyde for $30 \mathrm{~min}$. The islets were mounted as described previously, and the number of YoYolabeled nuclei per islet was counted by direct observation with a conventional epifluorescence microscope with a minimum of 50 islets examined per condition.

\section{Western blots}

Western blots were prepared from islets as described previously (Brelje et al. 2004). An equivalent amount of islet protein was loaded in each lane for electrophoresis. Sheep anti-glucokinase (provided by Dr Mark Magnuson, Vanderbilt University, Nashville, TN, USA) was used at a dilution of 1:6000. Bound antibodies were detected using a 1:30 000 dilution of alkaline phosphatase-conjugated donkey secondary antibodies (Jackson ImmunoResearch Laboratories) and the chemiluminescent substrate CPD-Star (Applied Biosystems, Foster City, CA, USA). A Bio-Rad GS-700 (Bio-Rad) was used for quantitative densitometry with the volume density of bands calculated as O.D. $\times \mathrm{mm}^{2}$ after background correction.

\section{Expression of data and statistics}

Data are expressed as the mean \pm s.E.M. of the number of observations. Statistical analysis was performed by the StudentNeuman-Keuls one-way ANOVA for multiple comparisons. Each treatment group within an experiment was replicated five times and each experiment repeated three to six times.

\section{Results}

\section{Effects of prolactin and palmitate on insulin secretion}

To investigate whether fatty acids can counteract the effects of prolactin on insulin secretion, islets were cultured for 8 days with $500 \mathrm{ng} / \mathrm{ml}$ prolactin, $0.4 \mathrm{mM}$ palmitate, or the combination of both prolactin and palmitate (Fig. 1A). The insulin secretion data are presented as fold increase over that of controls. With the exception of the first $24 \mathrm{~h}$ where there is an approximate $30 \%$ decrease in insulin values, the daily insulin release for the rest of the experiment remained stable. Prolactin or palmitate by themselves increased insulin released on day 1 and further increased it through day 3 after which it was maintained through the 8 days $(P<0 \cdot 05)$. The combination of both prolactin and palmitate was more effective than either alone $(P<0 \cdot 01)$. The cumulative insulin secretion was calculated as the sum of the daily values (Fig. 1B). A $2 \cdot 6$ - and $2 \cdot 8$-fold increase in insulin secretion was observed with prolactin or palmitate by themselves respectively $(P<0 \cdot 01)$. A $4 \cdot 8$-fold increase in insulin secretion
A
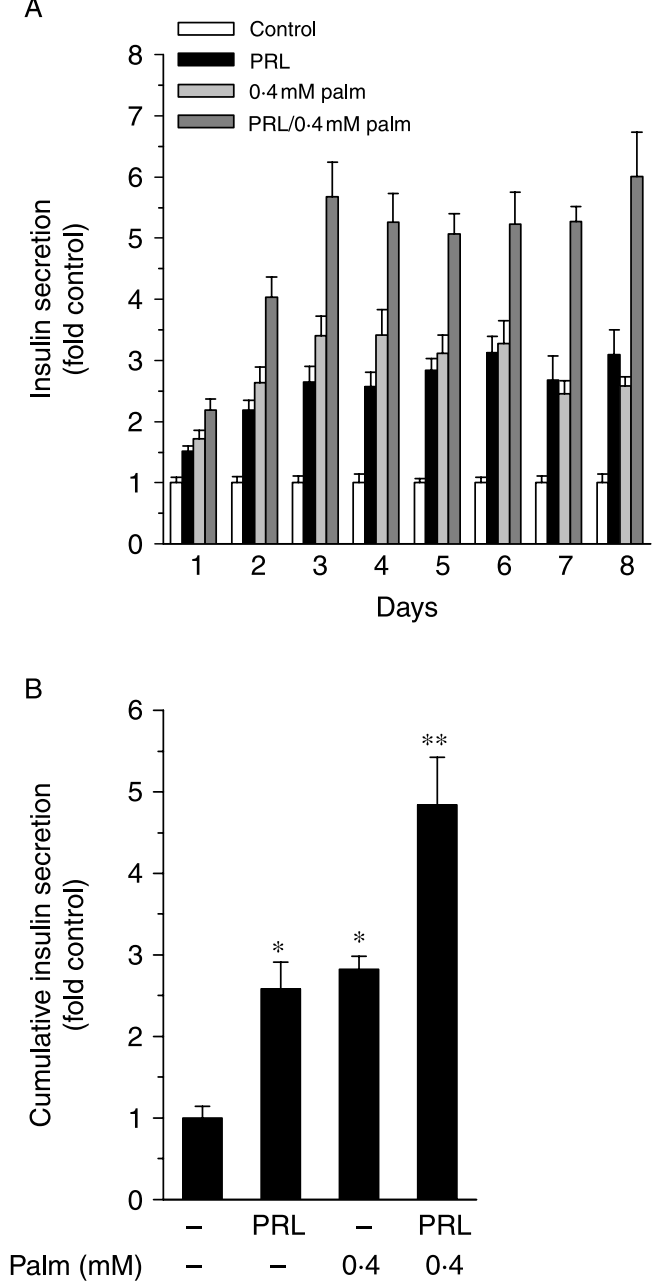

Figure 1 Effects of prolactin and palmitate on insulin secretion. Islets were cultured for 8 days with $500 \mathrm{ng} / \mathrm{ml}$ prolactin (PRL) and/or $0.4 \mathrm{mM}$ palmitate (Palm; $n=5$ ). (A) Insulin secretion was increased on all days with prolactin or palmitate by themselves $(P<0 \cdot 05)$. The combination of prolactin and palmitate was more effective than either alone on all days $(* * P<0 \cdot 01)$. (B) Cumulative insulin secretion was calculated as the sum of the daily values. Prolactin and/or palmitate increased insulin secretion by themselves $\left({ }^{*} P<0 \cdot 01\right)$ and in combination further increased insulin secretion compared with prolactin alone $\left({ }^{* *} P<0 \cdot 01\right)$.

was observed with the combination of both prolactin and palmitate $(P<0 \cdot 01)$. Although these results suggest that palmitate does not counteract the effects of prolactin on insulin secretion, differences in glucose-stimulated insulin release cannot be inferred from these data because of the presence of palmitate in the media.

\section{Effects of prolactin and palmitate on glucose-stimulated} insulin secretion

For a better estimate of actual differences in glucosestimulated insulin secretion, islets were stimulated with only 
glucose in 1-h static incubations after culture for 4 days with $500 \mathrm{ng} / \mathrm{ml}$ prolactin, $0.4 \mathrm{mM}$ palmitate, or the combination of both prolactin and palmitate. The islets were first stimulated with $5.6 \mathrm{mM}$ glucose to approximate their effects on basal insulin secretion at the normal serum glucose concentrations. Insulin release with $5.6 \mathrm{mM}$ glucose was increased from islets cultured with prolactin alone or in combination with palmitate (Fig. $2 \mathrm{~A}, P<0 \cdot 05$ ). The islets were then stimulated with $10 \mathrm{mM}$ glucose to examine their response to glucose stimulation. As expected from previous studies, insulin release with $10 \mathrm{mM}$ glucose was increased nearly twofold from islets cultured with only prolactin (Fig. 2A, $P<0 \cdot 05$ ), while it was reduced by $38 \%$ from islets cultured with only palmitate (Fig. 2A, $P<0 \cdot 05$ ). More importantly, insulin release with $10 \mathrm{mM}$ glucose was also reduced by $31 \%$ from islets cultured with both prolactin and palmitate compared with those cultured with only prolactin (Fig. 2A, $P<0 \cdot 05$ ). In this case, the extent of insulin release was now identical to that from control islets at $10 \mathrm{mM}$ glucose. This result demonstrates that palmitate can inhibit the effects of prolactin on insulin release at the higher glucose concentrations. This supports our hypothesis that fatty acids may counteract the effects of lactogens on insulin secretion stimulated with only glucose in late pregnancy.

However, this inhibition of glucose-stimulated insulin secretion by prior culture with palmitate is the opposite of the increase in insulin secretion during culture $(10 \mathrm{mM}$ glucose data of Fig. 2A versus Fig. 1). This suggested that the islets have adapted to the chronic elevation in fatty acids and are dependent on palmitate to maintain the normal responsiveness. To examine this possibility, additional trials were done to examine insulin release in $1-\mathrm{h}$ static incubations in the presence of $0.4 \mathrm{mM}$ palmitate. In islets cultured with only palmitate, the addition of palmitate to the stimulation media increased insulin release with $5.6 \mathrm{mM}$ glucose (Fig. 2B, $P<0.05)$ and reversed the inhibition of insulin release with $10 \mathrm{mM}$ glucose (Fig. 2B, $P<0 \cdot 05$ ). In the latter case, the extent of insulin release was now $1 \cdot 5$-fold higher than from control islets stimulated with only glucose. More important was the similar effects on insulin release from the islets cultured with both prolactin and palmitate. The addition of palmitate to the stimulation media further increased insulin release with $5.6 \mathrm{mM}$ glucose (Fig. $2 \mathrm{~B}, P<0 \cdot 05$ ). Remarkably, the extent of insulin release was now similar to that from control islets stimulated with only $10 \mathrm{mM}$ glucose (Fig. 2B). Similarly, the addition of palmitate to $10 \mathrm{mM}$ glucose also reversed the inhibition of insulin release from islets cultured with both prolactin and palmitate (Fig. $2 \mathrm{~B}, P<0 \cdot 05$ ). In this case, insulin release was now twofold higher than from islets cultured with only prolactin. (Also, note that the relative relationships between insulin release with $10 \mathrm{mM}$ glucose and $0.4 \mathrm{mM}$ palmitate in Fig. 2B matches the cumulative insulin secretion shown in Fig. 1B). These results demonstrate that prior culture with palmitate can actually enhance the effects of prolactin on insulin secretion when stimulated with glucose in the presence of palmitate. As this is the likely condition in vivo,
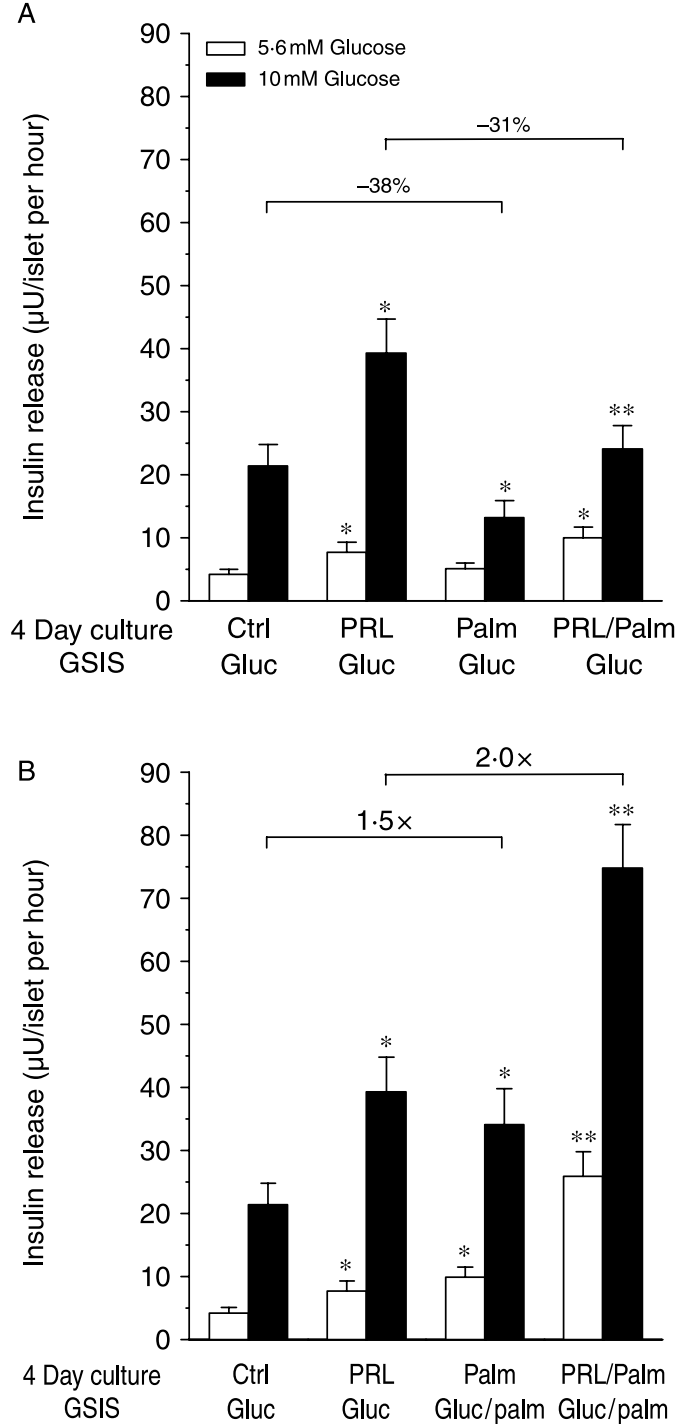

Figure 2 Glucose-stimulated insulin release (GSIS) in response to $5 \cdot 6$ (open bars) or $10 \mathrm{mM}$ (filled bars) glucose for $1 \mathrm{~h}$ from islets after prior culture for 4 days with $500 \mathrm{ng} / \mathrm{ml}$ prolactin (PRL) and/or $0.4 \mathrm{mM}$ palmitate (Palm). (A) At $5.6 \mathrm{mM}$ glucose, insulin release was increased from islets cultured with either prolactin or in combination with palmitate $\left({ }^{*} P<0 \cdot 05\right)$. At $10 \mathrm{mM}$ glucose, insulin release was increased from islets cultured with prolactin $(* P<0 \cdot 05)$. In contrast, prior culture with palmitate inhibited subsequent insulin release by itself $\left({ }^{*} P<0 \cdot 05\right)$ or in combination with prolactin $(* * P<0 \cdot 05$ versus prolactin alone). (B) Insulin release was also examined with $0.4 \mathrm{mM}$ palmitate in the stimulation media. At both 5.6 and $10 \mathrm{mM}$ glucose, the addition of palmitate increased insulin release from islets cultured with palmitate alone $\left({ }^{*} P<0 \cdot 05\right)$ or in combination with prolactin ( ${ }^{* *} P<0.05$ versus prolactin alone). The addition of palmitate to the stimulation media restores insulin release from islets cultured with palmitate alone or in combination with prolactin to levels above those from controls or cultured with prolactin alone respectively. Results are the means \pm s.E.M. of six separate experiments. 
it suggests that fatty acids may actually enhance rather than inhibit the effects of lactogens on insulin secretion in late pregnancy.

\section{Effects of prolactin and palmitate on islet cell proliferation}

To investigate whether fatty acids counteract the effects of prolactin on islet cell proliferation, islets were cultured for 4 or 8 days with $500 \mathrm{ng} / \mathrm{ml}$ prolactin either in the absence or presence of $0.4 \mathrm{mM}$ palmitate. The dividing cells were visualized by labeling with $\mathrm{BrdU}$ during the last $12-\mathrm{h}$ culture (Fig. 3A). As expected from previous studies (Brelje et al. 1994, 2004), the number of BrdU-labeled nuclei/islet was increased eightfold by prolactin $(P<0 \cdot 05)$. A smaller fourfold increase was observed with $0.4 \mathrm{mM}$ palmitate $(P<0 \cdot 05)$. Unexpectedly, the combination of prolactin and $0.4 \mathrm{mM}$ palmitate was slightly more than additive with a 17 -fold increase $(P<0 \cdot 05)$. Similar results were observed after 4 and 8 days. These results suggest that palmitate enhances rather than inhibits the effects of prolactin on islet cell proliferation.

To examine whether a higher concentration of palmitate inhibits the effects of prolactin on islet cell proliferation, additional trials were done with $0.8 \mathrm{mM}$ palmitate (Fig. 3A). The number of BrdU-labeled nuclei/islet was similar to the lower concentration of palmitate after 4 days with $0.8 \mathrm{mM}$ palmitate alone or in combination with prolactin $(P<0 \cdot 05)$. However, unlike the lower concentration of palmitate, these effects were absent after 8 days for both conditions. That this higher concentration of palmitate was deleterious to islets was supported by their irregular shape, signs of disintegration, and loss of islets. $(<20 \%$ of the islets were recovered after 8 days compared with $70 \%$ after 4 days regardless of the presence of prolactin). These results suggest that this higher concentration of palmitate also stimulates islet cell proliferation, but that prolonged exposure is toxic to $\beta$ cells under these culture conditions.

\section{Effects of prolactin and palmitate on islet cell viability}

To investigate the effects of prolactin and palmitate on islet cell viability, islets were cultured for 4 days with $500 \mathrm{ng} / \mathrm{ml}$ prolactin either in the absence or presence of 0.4 or $0.8 \mathrm{mM}$ palmitate. Dead cells were visualized by incubation with the YoYo-1, a cell impermeant nuclei acid stain, during the last 3-h culture (Fig. 3B). The low number of YoYo-labeled nuclei/islet was unchanged by either prolactin or $0.4 \mathrm{mM}$ palmitate by themselves or in combination. This result indicates that $0.4 \mathrm{mM}$ palmitate does not adversely affect islet cell viability after 4 days under these culture conditions. In contrast, there was a large increase in the number of YoYo-labeled nuclei with $0.8 \mathrm{mM}$ palmitate $(P<0 \cdot 01)$. This effect was substantially reduced by prolactin. These results indicate that the higher concentrations of palmitate decrease islet cell viability, but that its effects are partially blocked by the anti-apoptotic effects of prolactin on $\beta$ cells.
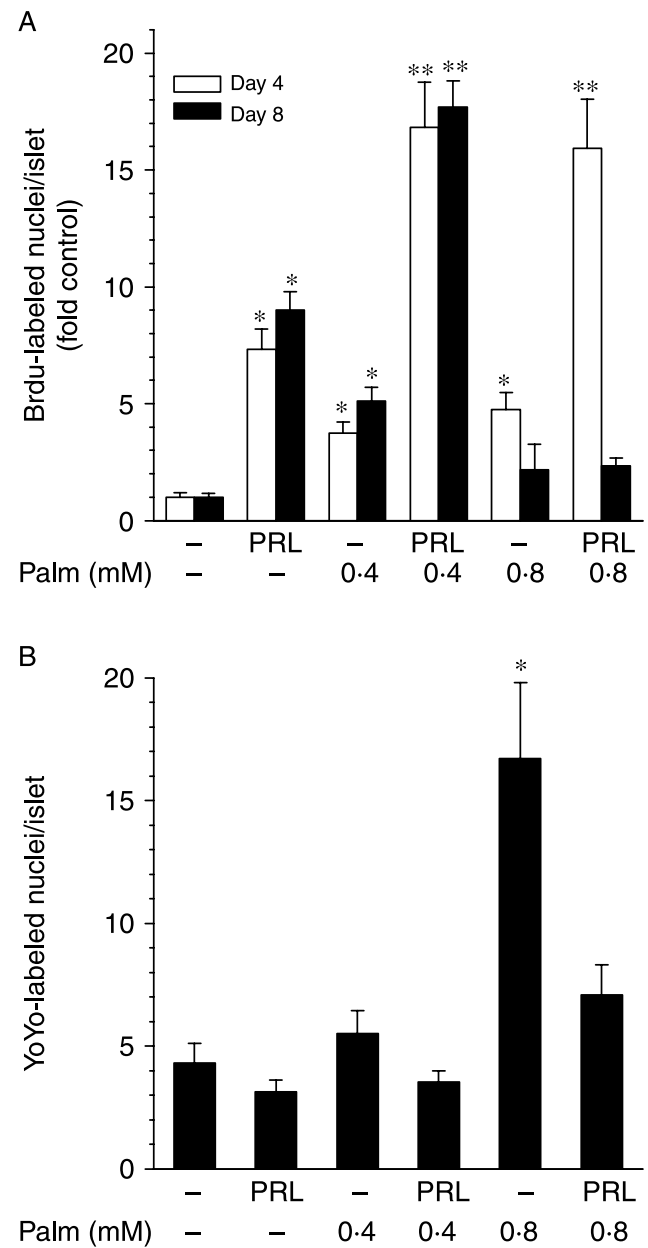

Figure 3 Effects of prolactin and palmitate on islet cell proliferation and viability. (A) Islets were cultured for 4 or 8 days with $500 \mathrm{ng} / \mathrm{ml}$ prolactin (PRL) and/or $0 \cdot 4 / 0 \cdot 8 \mathrm{mM}$ palmitate (Palm) and dividing cells visualized by labeling with BrdU during the last $12 \mathrm{~h}$. Islet cell proliferation was increased after both 4 and 8 days with prolactin or $0.4 \mathrm{mM}$ palmitate by themselves $\left({ }^{*} P<0 \cdot 05\right)$. The combination of prolactin and $0.4 \mathrm{mM}$ palmitate was more effective than either alone $\left({ }^{* *} P<0 \cdot 05\right.$ versus prolactin alone). Palmitate $(0 \cdot 8 \mathrm{mM})$ by itself or in combination with prolactin only increased islet cell proliferation after 4 days. Results are the means \pm s.E.M. of 75-100 islets per condition. (B) Islets were cultured for 4 days with $500 \mathrm{ng} / \mathrm{ml}$ prolactin (PRL) and/or 0.4/0.8 mM palmitate (Palm) and dead cells identified by staining with YoYo-1 during the last $3 \mathrm{~h}$. Only $0 \cdot 8 \mathrm{mM}$ palmitate increase the number of YoYo-labeled cells which was prevented by the addition of prolactin. Results are the means \pm S.E.M. of $75-100$ islets per condition. ${ }^{*} P<0 \cdot 01$.

\section{Dose-dependent effects of palmitate on islets}

Because the serum concentration of fatty acids gradually increase during the last half of pregnancy (Scow et al. 1964, Knopp et al. 1973, Chen et al. 1992), we examined whether the lower concentrations of palmitate were also effective in increasing insulin secretion and islet cell proliferation from islets cultured with prolactin. Islets were cultured for 4 days 
with $0.05-0.8 \mathrm{mM}$ palmitate either in the absence or presence of $500 \mathrm{ng} / \mathrm{ml}$ prolactin. Palmitate increased the cumulative insulin secreted into the media in a dosedependent manner at the concentrations of $0.1 \mathrm{mM}$ and higher (Fig. 4A, $P<0 \cdot 05$ ). In combination with prolactin, an increase was detected for the concentrations of $0.2 \mathrm{mM}$ and

A

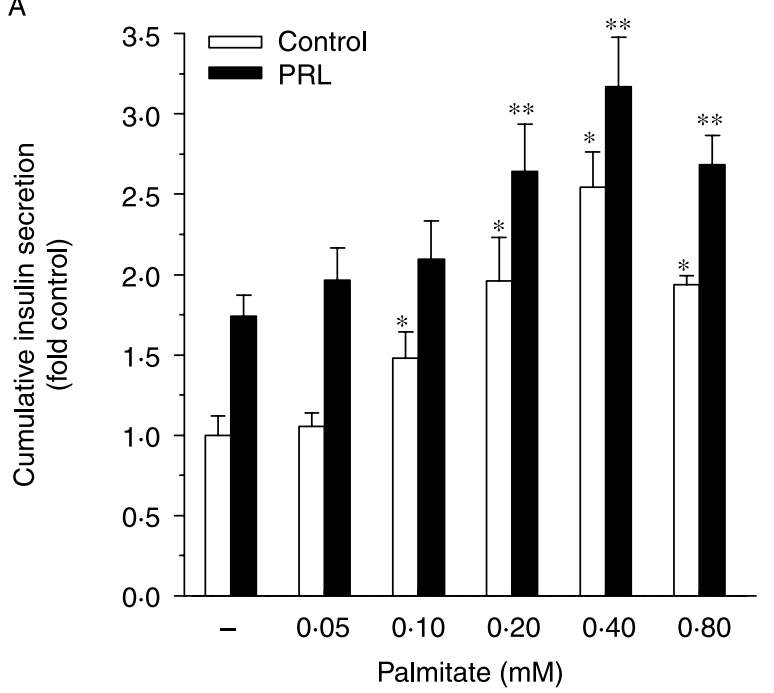

B

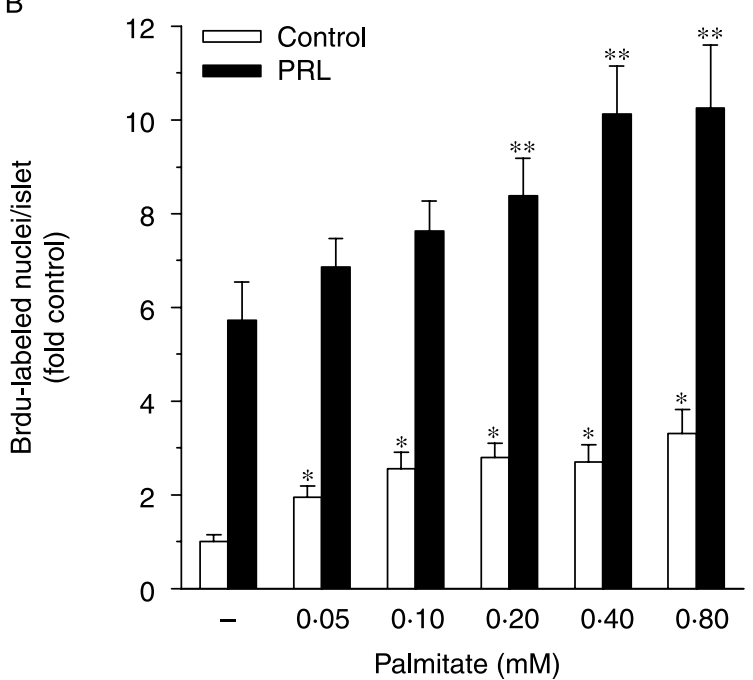

Figure 4 Dose-dependent effects of palmitate on insulin secretion and islet cell proliferation. Islets were cultured for 4 days with $500 \mathrm{ng} / \mathrm{ml}$ prolactin (PRL) and/or 0.05-0.8 mM palmitate. (A) Palmitate by itself increased insulin secretion in a dose-dependent manner at concentrations of $0.1 \mathrm{mM}$ and higher $\left({ }^{*} P<0 \cdot 05\right.$; $n=5$ ). Palmitate also increased insulin secretion with prolactin at concentrations of $0.2 \mathrm{mM}$ and higher $\left({ }^{* *} P<0 \cdot 05\right.$ versus prolactin alone, $n=5$ ). (B) Palmitate by itself increased the number of BrdUlabeled nuclei/islet in a dose-dependent manner at concentrations of $0.05 \mathrm{mM}$ and higher $\left({ }^{*} P<0.05\right)$. Palmitate also increased islet cell proliferation with prolactin at concentrations of $0.2 \mathrm{mM}$ and higher (**P<0.05 versus prolactin alone). Results are the means \pm S.E.M. of $75-100$ islets per condition. higher when compared with prolactin by itself (Fig. 4A, $P<0 \cdot 05)$. Similarly, palmitate increased the number of BrdU-labeled nuclei/islet in a dose-dependent manner at concentrations as low as $0.05 \mathrm{mM}$ and reached a maximum threefold increase at $0.8 \mathrm{mM}$ (Fig. $4 \mathrm{~B}, P<0 \cdot 05$ ). Prolactin by itself induced a sixfold increase. The combination of both prolactin and palmitate resulted in even larger increases at the concentrations of $0.2 \mathrm{mM}$ palmitate and higher compared with prolactin by itself (Fig. $4 \mathrm{~B}, P<0 \cdot 05$ ). These results demonstrate that the lower concentrations of palmitate can increase insulin secretion and islet cell proliferation suggesting the changes in serum levels of fatty acids may be sufficient to alter insulin secretion and islet cell proliferation during pregnancy.

\section{Effects of prolactin and oleate on islets}

Because the serum concentration of oleate also increases during the last half of pregnancy (Chen et al. 1992), we also examined whether oleate had similar effects on islet function. Islets were cultured for 4 days in the presence of $500 \mathrm{ng} / \mathrm{ml}$ prolactin either in the absence or presence of $0.4 \mathrm{mM}$ palmitate or oleate. Although palmitate increased insulin secretion from islets cultured by itself or in combination with prolactin, oleate had little effect on the cumulative insulin secreted into the medium whether by itself or in combination with prolactin (Fig. 5A). Likewise, differences were also observed in the intracellular insulin content of these islets (Table 1). Palmitate reduced insulin content $(P<0 \cdot 05)$. This reduction was prevented when in combination with prolactin. In contrast, oleate did not alter insulin content, but in combination with prolactin increased insulin content even higher than that with only prolactin $(P<0 \cdot 05)$. Unlike their differences on insulin secretion, both palmitate and oleate modestly increased the number of BrdU-labeled nuclei/islet by about threefold (Fig. 5B, $P<0 \cdot 05$ ). Prolactin by itself induced a sixfold increase that was further increased when in combination with either palmitate or oleate. Although the effects of prolactin and palmitate were slightly more than additive, the 21-fold increase with the combination of prolactin and oleate (Fig. 5B, $P<0 \cdot 01$ versus prolactin by itself) was more than twice the tenfold increase expected from adding together the effects of prolactin and oleate by themselves (note that the combinations of both palmitate and oleate gave similar results as expected from adding their individual responses, data not shown). Although these results suggest that oleate does not counteract the effects of prolactin on insulin secretion, oleate stimulates even larger increases in islet cell proliferation than palmitate when in combination with prolactin.

\section{Dose-response of the effects of oleate on islets}

To determine the dose-response effect of oleate on insulin secretion and islet cell proliferation, islets were cultured for 

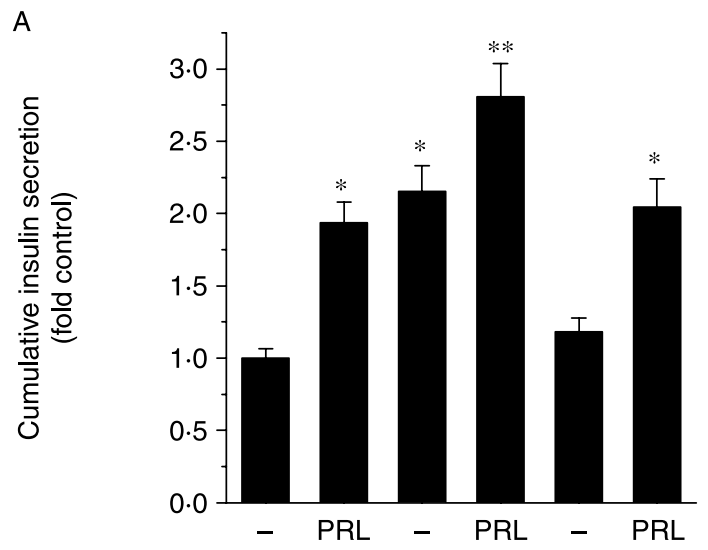

Fatty acid $(0.4 \mathrm{mM}) \quad$ _ $\quad$ - Palm Palm Ole Ole
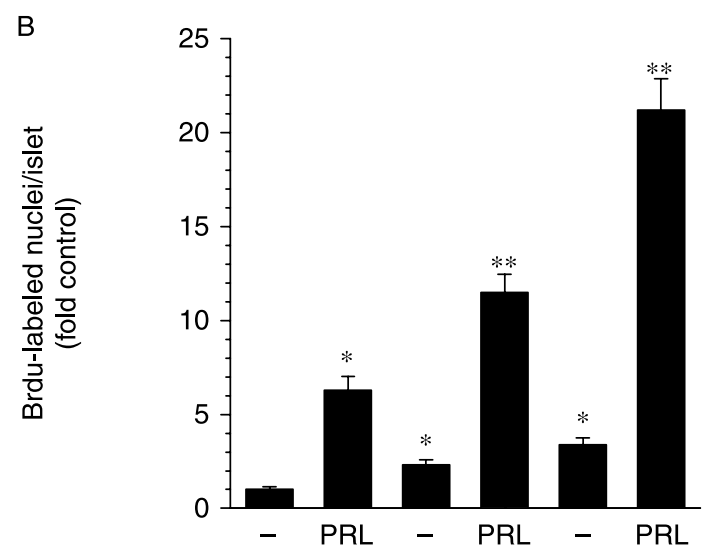

Fatty acid $(0.4 \mathrm{mM}) \quad$ - $\quad$ - Palm Palm Ole Ole

Figure 5 Effects of prolactin and oleate on insulin secretion and islet cell proliferation. Islets were cultured for 4 days with $500 \mathrm{ng} / \mathrm{ml}$ prolactin (PRL) and/or 0.4 mM palmitate (Palm)/oleate (Ole). (A) Although insulin secretion was increased by prolactin and palmitate, oleate by itself or in combination with prolactin did not further increase cumulative insulin secretion $(n=5)$. (B) Oleate by itself modestly increased the number of BrdU-labeled nuclei/islet $\left({ }^{*} P<0 \cdot 05\right)$. Although the effects of prolactin and palmitate are slightly more than additive, the combination of prolactin and oleate was more than twice the expected increase from adding together the effects of prolactin and oleate by themselves ( ${ }^{* *} P<0 \cdot 05$ versus prolactin alone). Results are the means \pm S.E.M. of $75-100$ islets per condition.

4 days with $500 \mathrm{ng} / \mathrm{ml}$ prolactin either in the absence or presence of $0.05-0.8 \mathrm{mM}$ oleate. As previously observed, oleate at the lower concentrations had no effect on the cumulative insulin secreted into the media whether by itself or in the presence of prolactin (Fig. 6A). In contrast, oleate increased the number of BrdU-labeled nuclei/islet in a dosedependent manner at concentrations as low as $0 \cdot 1 \mathrm{mM}$ (Fig. 6B, $P<0 \cdot 01$ ). In combination with prolactin, an increase was detected with concentrations as low as $0 \cdot 2 \mathrm{mM}$ oleate compared with prolactin by itself (Fig. $6 \mathrm{~B}, P<0 \cdot 05$ ). These results demonstrate that the lower concentrations of oleate also increase islet cell proliferation.

Table 1 Effects of palmitate and oleate on the intracellular insulin content of islets after culture with prolactin. The insulin content of islets was determined after culture for 4 days in the presence of $500 \mathrm{ng} / \mathrm{ml}$ prolactin either in the absence or presence of $0.4 \mathrm{mM}$ palmitate or oleate. The reduction in insulin content with palmitate was prevented by prolactin. In contrast, insulin content was unchanged by oleate but further increased the effects of prolactin

Insulin content (mU/islet)

\begin{tabular}{|c|c|}
\hline Control & $500 \mathrm{ng} / \mathrm{ml}$ prolactin \\
\hline $4 \cdot 35 \pm 0 \cdot 40$ & $5 \cdot 47 \pm 0 \cdot 58$ \\
\hline $2 \cdot 87 \pm 0 \cdot 18^{*}$ & $4 \cdot 33 \pm 0 \cdot 33$ \\
\hline $4 \cdot 85 \pm 0 \cdot 74$ & $6.93 \pm 0.69 *$ \\
\hline
\end{tabular}

Fatty acid

None

$0.4 \mathrm{mM}$ palmitate

$0 \cdot 4 \mathrm{mM}$ oleate

$* P<0 \cdot 05 ; n=5$
Effect of prolactin, palmitate, and oleate on glucokinase

Since fatty acid treatment has previously been shown to reduce the islet glucokinase levels (Gremlich et al. 1997) it was of interest to determine whether prolactin could prevent this from occurring. To examine this possibility, islets were cultured for 4 days with $500 \mathrm{ng} / \mathrm{ml}$ prolactin, $0.4 \mathrm{mM}$ palmitate or oleate, or a combination of prolactin with palmitate or oleate. When glucokinase expression was examined by western analysis, prolactin resulted in a 30\% increase in glucokinase whereas palmitate or oleate by themselves resulted in a $25-35 \%$ reduction in glucokinase (Fig. $7, P<0 \cdot 05$ ). When prolactin was combined with either palmitate or oleate, glucokinase levels were no longer inhibited by the presence of the fatty acids.

\section{Effects of prolactin and fatty acids in serum on islets}

Because all of our experiments were done in serum-free media with $1 \% \mathrm{BSA}$, we examined whether these fatty acids had similar effects on insulin secretion and $\beta$-cell proliferation in the presence of serum. Because the additional albumin in the horse serum will bind the small amount of free fatty acids, the concentration of fatty acids was increased to give comparable amounts with those in the serum-free media (see Materials and Methods).

Islets were cultured for 4 days with $500 \mathrm{ng} / \mathrm{ml}$ prolactin either in the absence or presence of $0.6 \mathrm{mM}$ palmitate or oleate in $10 \%$ horse serum. Although the addition of $1 \%$ fatty acid-free BSA to $10 \%$ horse serum did not affect insulin secretion (Fig. 8A), it surprisingly reduced the number of BrdU-labeled nuclei/islet by two-thirds in both control islets and those cultured with prolactin (Fig. 8B, $P<0 \cdot 05$ ). The dramatic decrease in cell division by the addition of fatty acidfree BSA suggests $\beta$ cells may require a basal level of fatty acids for the normal function. Nevertheless, the effects of palmitate or oleate by themselves or in combination with prolactin were similar to those observed in serum-free media. Insulin secretion was increased by palmitate by itself (Fig. 8A, $P<0 \cdot 01$ ) or in combination with prolactin (Fig. 8A, $P<0 \cdot 05$ versus prolactin by itself). Similarly, palmitate and oleate increased islet cell proliferation by themselves in serum 
A

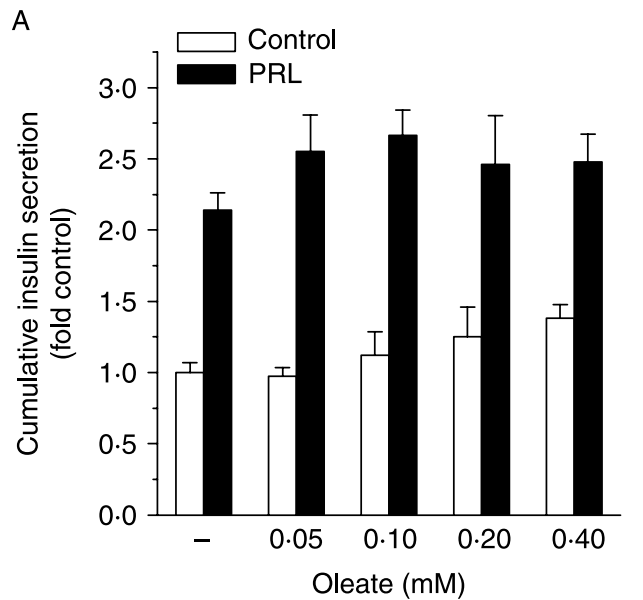

B

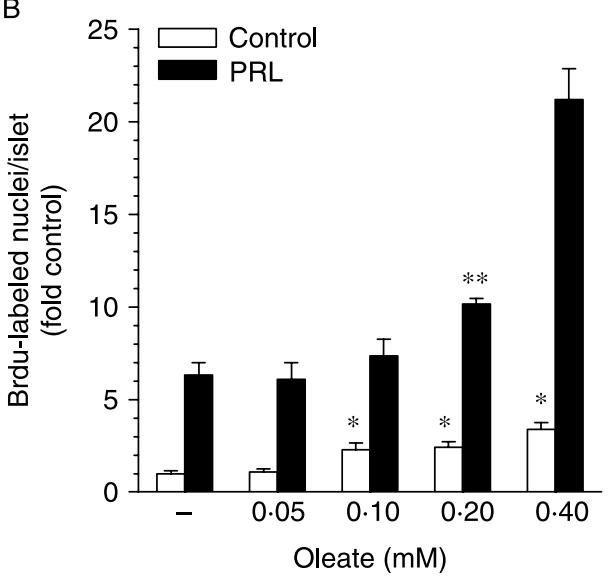

Figure 6 Dose-dependent effects of oleate on insulin secretion and islet cell proliferation. Islets were cultured for 4 days with $500 \mathrm{ng} / \mathrm{ml}$ prolactin (PRL) and/or 0.05-0.4 mM oleate. (A) Although insulin secretion was increased by prior culture with prolactin, oleate by itself or in combination with prolactin did not increase cumulative insulin secretion at any concentration $(n=5)$. (B) Oleate by itself increased the number of BrdU-labeled nuclei/islet in a dosedependent manner at concentrations of $0.1 \mathrm{mM}$ and higher $\left({ }^{*} P<0 \cdot 01\right)$. Oleate also increased islet cell proliferation with prolactin at concentrations of $0.2 \mathrm{mM}$ and higher $(* * P<0.05$ versus prolactin alone). Results are the means \pm s.E.M. of $75-100$ islets per condition.

(Fig. 8B, $P<0 \cdot 05)$. In combination with prolactin and palmitate was still nearly additive while oleate was synergistic (Fig. 8B, $P<0.05$ versus prolactin by itself). These observations show that the effects of prolactin in combination with palmitate or oleate on $\beta$-cell proliferation also occur in the presence of serum.

\section{Discussion}

This study examined whether the elevation in serum lipids during pregnancy could counteract the effects of lactogens on islets during late pregnancy. To examine this possibility, we

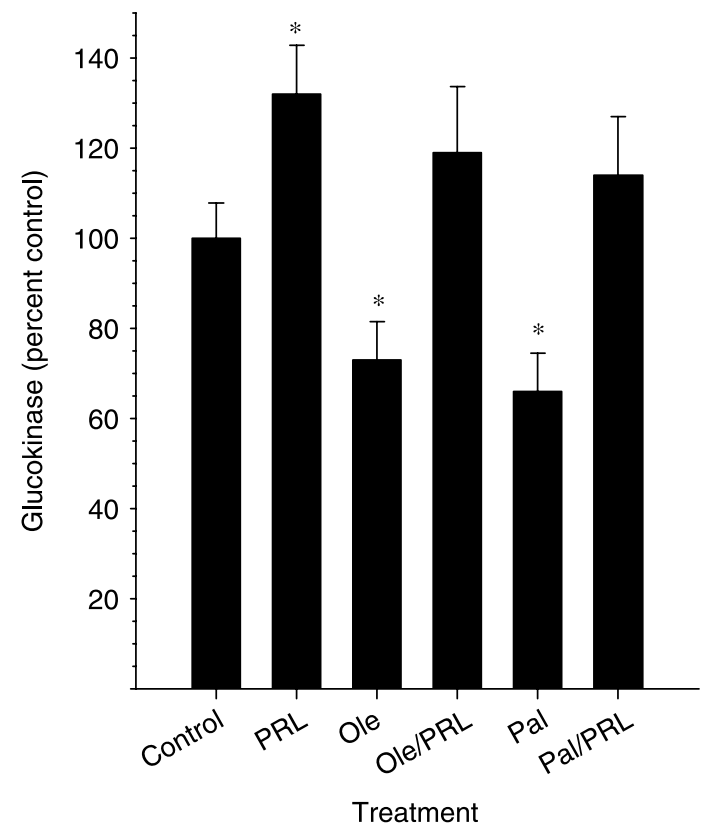

Figure 7 Effects of prolactin and fatty acids on glucokinase expression. Islets were cultured for $48 \mathrm{~h}$ with $500 \mathrm{ng} / \mathrm{ml}$ prolactin (PRL) and either $0.4 \mathrm{mM}$ palmitate (Pal) or oleate (Ole). The islets were examined by western blot analysis. Prolactin resulted in a $30 \%$ increase in glucokinase, whereas both fatty acids resulted in a $25-30 \%$ decrease in glucokinase. The combination of prolactin with either fatty acid prevented the inhibition of glucokinase by fatty acids. $\left({ }^{*} P<0 \cdot 05, n=4\right)$.

investigated the influence of fatty acids in the form of palmitate or oleate on the effects of prolactin in cultured islets. These conditions should mimic those islets experience during late pregnancy in vivo when they are exposed to high circulating levels of both lactogens and lipids. Insulin secretion was increased $2 \cdot 5$-fold from islets cultured with prolactin and/or palmitate (but not oleate) with the combination being additive. After culture with prolactin and palmitate, acute stimulation with $10 \mathrm{mM}$ glucose for $1 \mathrm{~h}$ showed suppression of insulin release. However, including palmitate in the stimulation media restored insulin release to even higher levels. These results provide new insight into the changes in insulin secretion that occur in late pregnancy. Prolactin also increased islet cell proliferation by sixfold, while palmitate and oleate stimulated smaller threefold increase. However, in combination with prolactin, palmitate had a slightly more than additive effect on islet cell proliferation (11-fold), while the effect of oleate was synergistic (21-fold). These observations suggest serum lipids may further enhance islet cell proliferation in mid-pregnancy and that some other factor(s) are responsible for the suppression of islet cell proliferation in late pregnancy.

Although our proposed model for regulation of $\beta$ cells by lactogens can account for the elevation of insulin secretion in mid-pregnancy, it cannot explain the return of glucosestimulated insulin secretion to the control levels as observed in 


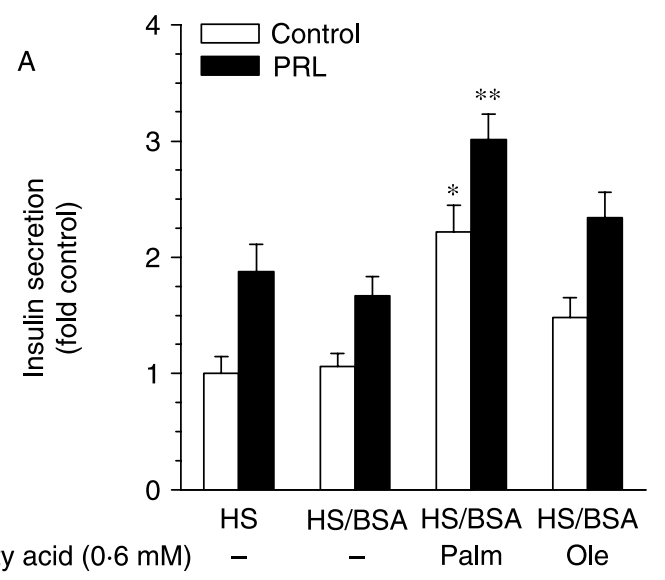

B

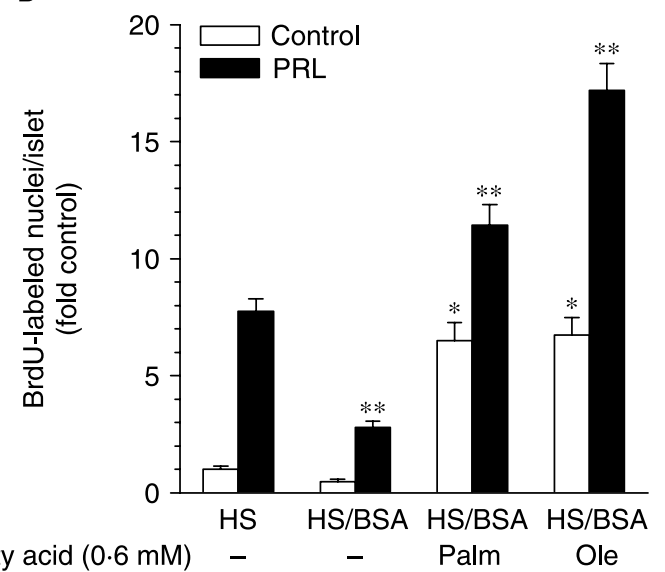

Figure 8 Effects of prolactin and fatty acids in serum on insulin secretion and islet cell proliferation. Islets were cultured for 4 days with $500 \mathrm{ng} / \mathrm{ml}$ prolactin (PRL) and either $0.4 \mathrm{mM}$ palmitate (Palm) or oleate (Ole) in $10 \%$ horse serum. (A) Insulin secretion was unaffected by the addition of $1 \%$ fatty acid-free BSA to $10 \%$ horse serum. As before, insulin secretion was increased by palmitate, but not oleate, by itself $\left({ }^{*} P<0 \cdot 01, n=5\right)$ or in combination with prolactin $\left({ }^{* *} P<0 \cdot 05\right.$ versus prolactin alone, $\left.n=5\right)$. (B) In contrast, the addition of $1 \%$ fatty acid-free BSA to $10 \%$ horse serum reduced the number of BrdU-labeled nuclei/islet by two-thirds in both control islets and those cultured with prolactin. However, similar to the results in the absence of horse serum, both palmitate and oleate increased islet cell proliferation by themselves $(* P<0 \cdot 05)$ or in combination with prolactin (**P<0.05 versus prolactin alone). Results are the means \pm s.E.M. of $75-100$ islets per condition.

late pregnancy. In our previous study, glucose-stimulated insulin secretion was examined ex vivo from pancreases of pregnant rats (Parsons et al. 1995). Insulin secretion peaked on day 15 of pregnancy after exposure in vivo to high circulating levels of lactogen for several days while serum lipids were still in a normal range. Insulin secretion then returned to control levels in late pregnancy after continued exposure in vivo to high circulating levels of lactogens and several days of elevated lipids. However, glucose tolerance tests have shown that insulin secretion in late pregnancy, although less than mid-pregnancy, is still higher than in non-pregnant individuals (Spellacy \& Goetz 1962, Leturque et al. 1980) and that the serum insulin levels remain elevated until parturition (Kawai \& Kishi 1999). This discrepancy between these ex vivo and in vivo observations has been puzzling. However, our experiments examining insulin release from islets cultured with prolactin and/or palmitate provides a possible explanation.

First, insulin release in response to only high glucose (i.e., $10 \mathrm{mM}$ ) suggests an explanation for the ex vivo observations. Insulin release was almost doubled in response to high glucose from islets cultured with only prolactin - a condition similar to mid-pregnancy with high circulating levels of lactogen. However, insulin release returned to the control levels in response to high glucose from islets cultured with prolactin and palmitate - a condition similar to late pregnancy with high circulating levels of lactogen and lipids. Thus, chronic exposure to palmitate suppressed the effects of prolactin on insulin release when stimulated with only high glucose in our model system. This observation suggests that elevated lipids in vivo may be responsible for the reduction in glucosestimulated insulin secretion to the control levels in late pregnancy from pancreases examined ex vivo (Parsons et al. 1995). In both cases, the islets have adapted to elevated fatty acids but are being stimulated with only glucose.

Second, insulin release in response to high glucose (i.e., $10 \mathrm{mM}$ ) in the presence of palmitate suggests an explanation for the in vivo observations. For islets cultured with prolactin and palmitate, insulin release in response to high glucose in the presence of palmitate was now almost double that from islets cultured with only prolactin and stimulated with only high glucose. Thus, chronic exposure to palmitate further enhances the effects of prolactin on insulin release when stimulated with high glucose in the presence of palmitate in our model system. This suggests that the elevation in lipids during pregnancy leads to enhanced rather than reduced insulin secretion in late pregnancy in vivo. This would explain why glucose tolerance tests appear better throughout pregnancy than in non-pregnant individuals (Spellacy \& Goetz 1962, Leturque et al. 1980).

Third, insulin release was dramatically elevated in response to glucose in the range of normal serum concentrations (i.e., $5.6 \mathrm{mM}$ ) from islets cultured with prolactin and palmitate. Remarkably, the extent of insulin release was now similar to that from control islets stimulated with only $10 \mathrm{mM}$ glucose. Thus, lipids should induce an increase in basal insulin secretion during pregnancy. This is consistent with the maintenance of elevated serum insulin levels until parturition (Kawai \& Kishi 1999).

Overall, these results suggest that the elevated insulin secretion in mid-pregnancy is primarily due to the effects of lactogen on islets. As pregnancy progresses, the increase in circulating levels of lipids induces a further adaptation in the islets. By late pregnancy, insulin secretion is less sensitive to glucose stimulation and becomes more dependent on the presence of fatty acids. This situation allows the maintenance 
of elevated insulin secretion until parturition and provides a mechanism for the rapid return to normal glucose sensitivity and insulin secretion in the early postpartum period when lipids return to non-pregnant levels.

It is noteworthy that our results are similar to the studies investigating insulin secretion from fasting animals both in vivo and ex vivo (Stein et al. 1996, Dobbins et al. 1998). Insulin secretion was reduced by $80 \%$ from perfused pancreases ex vivo after fasting. However, insulin secretion in vivo was not similarly decreased. This suggested another factor was responsible for maintaining insulin secretion in vivo but was absent ex vivo. This circulating factor was free fatty acids. The simple addition of palmitate to the perfusion media boosted insulin secretion from the fasted pancreas, so that it was $80 \%$ greater than that from fed pancreases challenged only with glucose. Similarly, in our studies, insulin release from islets cultured with palmitate is reduced by $40 \%$ when stimulated with glucose alone (Fig. 2A) and increased 1.5-fold when stimulated with glucose and palmitate (Fig. 2B).

Fatty acids have been shown to inhibit the expression of glucokinase (Gremlich et al. 1997). However, in late pregnancy, glucokinase is not suppressed (Weinhaus et al. 1996). Since fatty acids are at their highest levels at the end of pregnancy (Scow et al. 1964, Knopp et al. 1973, Chen et al. 1992), it was unclear why islet glucokinase was not suppressed at this time. Therefore, it was of interest to determine if prolactin could prevent the inhibitory effects of fatty acids on glucokinase. Our results confirm that fatty acids are capable of reducing islet glucokinase and importantly their effects can be prevented by prolactin. Thus, prolactin may be preventing the suppression of glucokinase in late pregnancy that should otherwise occur with the elevated serum levels of fatty acids.

Although the increase in lipids during pregnancy may account for the changes in insulin secretion in late pregnancy, the results from our experiments examining islet cell proliferation in islets cultured with prolactin and/or palmitate were unexpected. In our previous study, $\beta$-cell division peaked in mid-pregnancy and returned to the control levels by day 18 of pregnancy in rats (Parsons et al. 1995). Although insulin secretion remains elevated during an artificial prolongation of pregnancy, $\beta$-cell division still remains at the control levels after day 18 (Kawai \& Kishi 1999). Our original hypothesis was that fatty acids would counteract the effects of prolactin on $\beta$-cell division. This would provide a mechanism for the return to control levels in late pregnancy. However, palmitate by itself had a small stimulatory effect on islet cell proliferation which was slightly more than additive with the effect of prolactin. Thus, it is unlikely that elevated lipids in late pregnancy are responsible for the reduction in $\beta$-cell division to the control levels. Rather, it may contribute to the increase in $\beta$-cell division in mid-pregnancy because serum lipids start to increase as early as days 12-14 of pregnancy in rats (Scow et al. 1964, Knopp et al. 1973). In a large number of in vitro studies, we have consistently observed a sixfold increase in $\beta$-cell division with prolactin. During pregnancy in rats, the increase in $\beta$-cell division has been reported to peak at eight- to tenfold in mid-pregnancy by several groups (Parsons et al. 1992, Nieuwenhuizen et al. 1998, Kawai \& Kishi 1999). This is comparable with what was observed in this study with lower concentrations of palmitate or oleate in combination with prolactin. This suggests that fatty acid concentrations characteristic of pregnancy may enhance rather than inhibit $\beta$-cell division.

The combination of prolactin and higher concentrations of oleate was unusual in that it had a synergistic effect on islet cell proliferation. In previous experiments, we have examined a large number of growth factors on islets by themselves and in combination with prolactin. Prolactin has always been the most potent growth factor examined and in combination with other growth factors have, at best, been additive with prolactin (Brelje \& Sorenson 1997). In this study, islet cell proliferation was increased more than twice that expected from adding together the effects of prolactin and $0.4 \mathrm{mM}$ oleate by themselves. In this case, islet cell division was increased 6-fold with prolactin, 3-fold with oleate by itself, and 21-fold with the combination of both prolactin and oleate. This is the largest increase in growth promotion of islets in culture that we have observed. Although the reasons are unknown, synergy between IGF-1 and oleate on cell division in smooth muscle cells has been reported (Askari et al. 2002).

Although fatty acids can induce a large expansion of $\beta$-cell mass in vivo (Prentki \& Nolan 2006), most studies have focused on the ability of saturated fatty acids, such as palmitate, to repress insulin gene expression, glucosestimulated insulin secretion, and induce apoptosis in $\beta$ cells (Nolan et al. 2006, Poitout et al. 2006). Their effect on $\beta$-cell replication has been a minor aspect of these studies except for those with $\beta$-cell lines. In general, palmitate appears to stimulate apoptosis and either reduce (Cousin et al. 2001, Xiao et al. 2002), or less frequently have no affect (Roche et al. 1999) on cell division in $\beta$-cell lines. Palmitate also prevents the stimulation of cell division by glucose or IGF-1 in INS-1 cells (Cousin et al. 2001). In contrast, oleate either stimulates (Roche et al. 1999) or has no affect (Higa et al. 2006) on cell proliferation in $\beta$-cell lines. However, studies with Zucker diabetic fatty rats noted that culturing islets from non-diabetic rats with a 2:1 mixture of palmitate:oleate for 7 days increases $\beta$-cell replication by threefold (Milburn et al. 1995, Hirose et al. 1996). Similarly, the infusion of rats with Intralipid for 4 days also increased $\beta$-cell mass by $54 \%$ and $\beta$-cell proliferation by $2 \cdot 2$-fold (Steil et al. 2001). Finally, palmitate was shown to slightly decrease and oleate to slightly increase $\beta$-cell proliferation in cultured human islets (Maedler et al. 2003). Overall, our observations provide further evidence that under certain conditions palmitate or oleate can enhance cell division in the normal $\beta$ cells. This suggests that non-toxic concentrations of fatty acids may have beneficial effects on $\beta$-cell division in cultured islets. Further studies are needed to clarify their effects on the regulation of $\beta$-cell proliferation and their interactions with other $\beta$-cell growth factors.

It remains to be determined which factor(s) is responsible for the decline in $\beta$-cell proliferation from the peak in 
mid-pregnancy to the control levels by parturition (Parsons et al. 1992, Nieuwenhuizen et al. 1998, Kawai \& Kishi 1999). In previous studies, we have shown that progesterone (Sorenson et al. 1993) or glucocorticoids (Weinhaus et al. 2000) can counteract the stimulation of insulin secretion and $\beta$-cell proliferation by lactogens in cultured islets. Female mice lacking the progesterone receptor have an increase in islet mass and $\beta$-cell proliferation (Picard et al. 2002). In another study, progesterone given to pregnant rats increased $\beta$-cell replication in mid-pregnancy, but did not prevent the decline to the control levels in late pregnancy (Nieuwenhuizen et al. 1998). Although this supports a stimulatory role for progesterone on $\beta$-cell division, it is also compatible with the proposal that prolonged treatment with progesterone may lead to counteraction of the proliferation effect of lactogens (Sorenson et al. 1993). The effect of glucocorticoids on $\beta$ cells is most likely restricted to the last $1-2$ days as this would correlate with their peak serum levels.

A recent paper from the laboratory of Seung K Kim provides further insights into the regulation of $\beta$-cell proliferation during pregnancy (Kamik et al. 2007). Prolactin stimulates the JAK2/STAT5 pathway and induces the expression of targets like $\mathrm{Bcl} 6 . \mathrm{Bcl} 6$ is a transcriptional repressor of Men 1 and reduces the expression of the protein menin. Menin functions as a complex that maintains expression of $\mathrm{p} 27^{\mathrm{Kip} 1}$ and $\mathrm{p} 18^{\mathrm{INK} 4 \mathrm{C}}$ which encode cyclindependent kinase inhibitors that prevent proliferation. They also showed that progesterone and dexamethasone partially reversed the effects of prolactin on menin expression. These data are particularly interesting because progesterone has been shown to increase the expression of $\mathrm{p} 21^{\mathrm{cip}}$ and $\mathrm{p} 27^{\mathrm{Kip} 1}$ and inhibit the growth of breast cancer cells (Owen et al. 1998, Gizard et al. 2005). It is also interesting that prolactin increases the expression of $\mathrm{p} 21^{\text {cip }}$ in $\beta$ cells (Cozar-Castellano et al. $2006 a, b)$. Although progesterone remains an interesting candidate for the suppression of $\beta$-cell replication in late pregnancy, further investigation is required.

In summary, this study provides evidence in support of the hypothesis that increasing concentrations of fatty acids contribute to the adaptation of islets to pregnancy. At midpregnancy, the elevated insulin secretion is largely accounted for by the effects of lactogens on islets. As circulating levels of lipids increase during pregnancy, the islets adapt to their continued presence and become less sensitive to glucose stimulation and more dependent on fatty acids. Although lactogens are primarily responsible for the increased $\beta$-cell division during pregnancy, fatty acids may also contribute to the large increase in $\beta$-cell division.

\section{Acknowledgements}

This research was supported by NIH grant DK33655. The authors declare that there is no conflict of interest that would prejudice the impartiality of this scientific work.

\section{References}

Askari B, Carroll MA, Capparelli M, Kramer F, Gerrity RG \& Bornfeldt KE 2002 Oleate and linoleate enhance the growth-promoting effects of insulinlike growth factor-I through a phospholipase D-dependent pathway in arterial smooth muscle cells. Journal of Biological Chemistry 277 36338-36344.

Brelje TC \& Sorenson RL 1988 Nutrient and hormonal regulation of the threshold of glucose-stimulated insulin secretion in isolated rat pancreases. Endocrinology 123 1582-1590.

Brelje TC \& Sorenson RL 1991 Role of prolactin versus growth hormone on islet B-cell proliferation in vitro: implications for pregnancy. Endocrinology 128 45-57.

Brelje TC \& Sorenson RL 1997 The physiological roles of prolactin, growth hormone and placental lactogen in the regulation of islet beta cell proliferation. In Pancreatic Growth and Regeneration, pp 1-30. Ed. N Sarvetnik. New York: Karger Landes Systems.

Brelje TC, Allaire P, Hegre O \& Sorenson RL 1989 Effect of prolactin versus growth hormone on islet function and the importance of using homologous mammosomatotropic hormones. Endocrinology 125 2392-2399.

Brelje TC, Scharp DW, Lacy PE, Ogren L, Talamantes F, Robertson M, Friesen HG \& Sorenson RL 1993 Effect of homologous placental lactogens, prolactins, and growth hormones on islet B-cell division and insulin secretion in rat, mouse, and human islets: implication for placental lactogen regulation of islet function during pregnancy. Endocrinology 132 879-887.

Brelje TC, Parsons JA \& Sorenson RL 1994 Regulation of islet $\beta$-cell proliferation by prolactin in rat islets. Diabetes 43 263-273.

Brelje TC, Stout LE, Bhagroo NV \& Sorenson RL 2004 Distinctive roles for prolactin and growth hormone in the activation of signal transducer and activator of transcription 5 in pancreatic islets of langerhans. Endocrinology 145 4162-4175.

Briaud I, Harmon JS, Kelpe CL, Segu VB \& Poitout V 2001 Lipotoxicity of the pancreatic $\beta$-cell is associated with glucose-dependent esterification of fatty acids into neutral lipids. Diabetes $\mathbf{5 0} 315-321$.

Chen ZY, Yang J \& Cunnane SC 1992 Gestational hyperlipidemia in the rat is characterized by accumulation of $n-6$ and $n-3$ fatty acids, especially docosahexaenoic acid. Biochimica et Biophysica Acta 1127 263-269.

Cousin SP, Hugl SR, Wrede CE, Kajio H, Myers MG Jr \& Rhodes CJ 2001 Free fatty acid-induced inhibition of glucose and insulin-like growth factor I-induced deoxyribonucleic acid synthesis in the pancreatic $\beta$-cell line INS-1. Endocrinology 142 229-240.

Cozar-Castellano I, Haught M \& Stewart AF 2006a The cell cycle inhibitory protein $\mathrm{p} 21$ cip is not essential for maintaining beta-cell cycle arrest or betacell function in vivo. Diabetes 55 3271-3278.

Cozar-Castellano I, Weinstock M, Haught M, Velazquez-Garcia S, Sipula D \& Stewart AF $2006 b$ Evaluation of beta-cell replication in mice transgenic for hepatocyte growth factor and placental lactogen: comprehensive characterization of the G1/S regulatory proteins reveals unique involvement of p21cip. Diabetes 55 70-77.

Dobbins RL, Chester MW, Daniels MB, McGarry JD \& Stein DT 1998 Circulating fatty acids are essential for efficient glucose-stimulated insulin secretion after prolonged fasting in humans. Diabetes 47 1613-1618.

Gizard F, Robillard R, Gervois P, Faucompre A, Revillion F, Peyrat JP, Hum WD \& Staels B 2005 Progesterone inhibits human breast cancer cell growth through transcriptional upregulation of the cyclin-dependent kinase inhibitor p27Kip1 gene. FEBS Letters 579 5535-5541.

Gremlich S, Bonny C, Waeber G \& Thorens B 1997 Fatty acids decrease IDX-1 expression in rat pancreatic islets and reduce Glut2, glucokinase, insulin, and somatostatin levels. Journal of Biological Chemistry 272 30261-30269.

Hegre OD, Marshall S, Schulte BA, Hickey GE, Williams F, Sorenson RL \& Serie JR 1983 Nonenzymic in vitro isolation of perinatal islets of Langerhans. In Vitro 19 611-620.

Higa M, Shimabukuro M, Shimajiri Y, Takasu N, Shinjyo T \& Inaba T 2006 Protein kinase $\mathrm{B} / \mathrm{Akt}$ signalling is required for palmitate-induced $\beta$-cell lipotoxicity. Diabetes, Obesity and Metabolism 8 228-233. 
Hirose H, Lee YH, Inman LR, Nagasawa Y, Johnson JH \& Unger RH 1996 Defective fatty acid-mediated beta-cell compensation in Zucker diabetic fatty rats. Pathogenic implications for obesity-dependent diabetes. Journal of Biological Chemistry 271 5633-5637.

Karnik SK, Chen H, McLean GW, Heit JJ, Gu X, Zhang AY, Fontaine M, Yen MH \& Kim SK 2007 Menin controls growth of pancreatic $\beta$-cells in pregnant mice and promotes gestational diabetes mellitus. Science 318 806-809.

Kawai M \& Kishi K 1999 Adaptation of pancreatic islet $\beta$-cells during the last third of pregnancy: regulation of $\beta$-cell function and proliferation by lactogenic hormones in rats. European Journal of Endocrinology 141 419-425.

Knopp RH, Saudek CD, Arky RA \& O'Sullivan JB 1973 Two phases of tissue metabolism in pregnancy: maternal adaptations for fetal growth. Endocrinology 92 984-988.

Leturque A, Ferre P, Satabin P, Kervran A \& Girard J 1980 In vivo insulin resistance during pregnancy in the rat. Diabetologia 19 521-528.

Maedler K, Oberholzer J, Bucher P, Spinas GA \& Donath MY 2003 Monounsaturated fatty acids prevent the deleterious effects of palmitate and high glucose on human pancreatic $\beta$-cell turnover and function. Diabetes $\mathbf{5 2}$ 726-733.

Milburn JL Jr, Hirose H, Lee YH, Nagasawa Y, Ogawa A, Ohneda M, BeltrandelRio H, Newgard CB, Johnson JH \& Unger RH 1995 Pancreatic $\beta$-cells in obesity. Evidence for induction of functional, morphologic, and metabolic abnormalities by increased long chain fatty acids. Journal of Biological Chemistry 270 1295-1299.

Nieuwenhuizen AG, Schuiling GA, Hilbrands LG, Bisschop EM \& Koiter TR 1998 Proliferation of pancreatic islet-cells in cyclic and pregnant rats after treatment with progesterone. Hormone Metabolic Research 30 649-655.

Nolan CJ, Madiraju MS, Delghingaro-Augusto V, Peyot ML \& Prentki M 2006 Fatty acid signaling in the $\beta$-cell and insulin secretion. Diabetes $\mathbf{5 5}$ S16-S23.

Owen GI, Richer JK, Tung L, Takimoto G \& Horwitz KB 1998 Progesterone regulates transcription of the p21(WAF1) cyclin-dependent kinase inhibitor gene through Sp1 and CBP/p300. Journal of Biological Chemistry 273 1069610701.

Parsons JA, Brelje TC \& Sorenson RL 1992 Adaptation of islets of Langerhans to pregnancy: increased islet cell proliferation and insulin secretion correlates with the onset of placental lactogen secretion. Endocrinology 130 1459-1466.

Parsons JA, Bartke A \& Sorenson RL 1995 Number and size of islets of Langerhans in pregnant, human growth hormone-expressing transgenic, and pituitary dwarf mice: effect of lactogenic hormones. Endocrinology $1362013-2021$.

Picard F, Wanatabe M, Schoonjans K, Lydon J, O’Malley BW \& Auwerx J 2002 Progesterone receptor knockout mice have an improved glucose homeostasis secondary to $\beta$-cell proliferation. PNAS 99 15644-15648.

Poitout V, Hagman D, Stein R, Artner I, Robertson RP \& Harmon JS 2006 Regulation of the insulin gene by glucose and fatty acids. Journal of Nutrition $136873-876$.
Prentki M \& Nolan CJ 2006 Islet beta cell failure in type 2 diabetes. Journal of Clinical Investigation 116 1802-1812.

Richieri GV, Anel A \& Kleinfeld AM 1993 Interactions of long-chain fatty acids and albumin: determination of free fatty acid levels using the fluorescent probe ADIFAB. Biochemistry 32 7574-7580.

Roche E, Buteau J, Aniento I, Reig JA, Soria B \& Prentki M 1999 Palmitate and oleate induce the immediate-early response genes c-fos and nur-77 in the pancreatic $\beta$-cell line INS-1. Diabetes 48 2007-2014.

Scow RO, Chernick SS \& Brinley MS 1964 Hyperlipemia and ketosis in the pregnant rat. American Journal of Physiology 206 796-804.

Sorenson RL \& Brelje TC 1997 Adaptation of islets of Langerhans to pregnancy: $\beta$-cell growth, enhanced insulin secretion and the role of lactogenic hormones. Hormone Metabolic Research 29 301-307.

Sorenson RL, Brelje TC \& Roth C 1993 Effects of steroid and lactogenic hormones on islets of Langerhans: a new hypothesis for the role of pregnancy steroids in the adaptation of islets to pregnancy. Endocrinology 133 2227-2234.

Spellacy WN \& Goetz FC 1962 Plasma insulin in normal late pregnancy. New England Journal of Medicine 268 988-991.

Steil GM, Trivedi N, Jonas JC, Hasenkamp WM, Sharma A, Bonner-Weir S \& Weir GC 2001 Adaptation of beta-cell mass to substrate oversupply: enhanced function with normal gene expression. American Journal of Physiology. Endocrinology and Metabolism 280 E788-E796.

Stein DT, Esser V, Stevenson BE, Lane KE, Whiteside JH, Daniels MB, Chen S \& McGarry JD 1996 Essentiality of circulating fatty acids for glucosestimulated insulin secretion in the fasted rat. Journal of Clinical Investigation $972728-2735$.

Weinhaus AJ, Stout LE \& Sorenson RL 1996 Glucokinase, hexokinase, glucose transporter 2, and glucose metabolism in islets during pregnancy and prolactin-treated islets in vitro: mechanisms for long term up-regulation of islets. Endocrinology 137 1640-1649.

Weinhaus A, Bhagroo NV, Brelje TC \& Sorenson RL 2000 Dexamethasone counteracts the effect of prolactin on islet function: implications for islet regulation in late pregnancy. Endocrinology 141 1384-1393.

Xiao J, Gregersen S, Pedersen SB \& Hermansen K 2002 Differential impact of acute and chronic lipotoxicity on gene expression in INS-1 cells. Metabolism 51 155-162.

Zimmerman NI, Wickler SJ, Rodiek AV \& Hower MA 1992 Free fatty acids in exercising Arabian horses fed two common diets. Journal of Nutrition 122 $145-150$.

Received in final form 29 January 2008

Accepted 21 February 2008

Made available online as an Accepted Preprint

21 February 2008 